\title{
Overvektig eller fet - du er ikke din lidelse
}

\author{
Stigmatiserende og diskriminerende personkarakteristikker som «fet(e)»og «overvektig(e)» bør unngås \\ i Tidsskriftet.
}

Det er generell enighet om at folk ikke bør karakteriseres ved sin lidelse eller sykdom. Temaet har vært omtalt flere ganger i Tidsskriftet tidligere $(1,2)$. Man bør unngå merkelapper som epileptiker, diabetiker, funksjonshemmet og utviklingshemmet fordi slike karakteristikker kan virke både diskriminerende, stigmatiserende og støtende.

Likevel bruker dessverre de fleste av oss, inkludert undertegnede, regelmessig betegnelser som «overvektige» eller «fete», både i populærvitenskapelige sammenhenger og i vitenskapelige artikler (3). To søk 5.5. 2015 på henholdsvis «overvektige» og «fete» i Tidsskriftet ga 308 og 116 treff, mange av dem av nyere årgang.

Derfor ble jeg både glad og overrasket da jeg leste at redaktørene i det amerikanske tidsskriftet Obesity tok et leserinnlegg om «the need for people-first language» på alvor $(4,5)$. De svarte resolutt at de heretter skal gjøre sitt beste for å unngå bruk av ord som «obese» (fet) for å beskrive individer. De vil umiddelbart endre sine retningslin- jer, og redaksjonen vil systematisk erstatte adjektivet «fet(e)» med substantivet «fedme» i fremtidige artikler.

Et konkret eksempel kan være å erstatte «sykelig overvektige personer» med «personer med sykelig overvekt». Undertegnede vil prøve å endre praksis fra dags dato. Jeg utfordrer Tidsskriftets redaktør til å følge sine amerikanske kollegers eksempel.

\section{Jøran Hjelmesæth}

joran.hjelmeseth@siv.no

Senter for sykelig overvekt i Helse Sør-Øst Sykehuset i Vestfold

Avdeling for endokrinologi, sykelig overvekt og

forebyggende medisin

Medisinsk klinikk, Institutt for klinisk medisin,

Universitetet i Oslo.

Jøran Hjelmesæth (f. 1957) er professor dr.med. og spesialist i indremedisin og i nyresykdommer. Han leder tverrfaglig poliklinikk og forskningsgruppen ved overvektssenteret.
Litteratur

1. Nakken KO. Betegnelsen epileptiker bør unngås. Tidsskr Nor Legeforen 2013; 133: 1088.

2. Nylund MF. Funksjonshemmet? Tidsskr Nor Legeforen 2009; 129: 1491

3. Hjelmesæth J. Randomiserte studier - nyttige for hvem? Tidsskr Nor Legeforen 2014; 134: 1819.

4. Dietz WH. The need for people-first language in our obesity journal. Obesity (Silver Spring) 2015 23: 917.

5. Ravussin E, Ryan D. Response to «the need for people-first language in our obesity journal». Obesity (Silver Spring) 2015; 23: 918.

Mottatt 7.5. 2015 og godkjent 11.6. 2015. Redaktør: Erlend Hem.

Publisert først på nett.

DLngelsk oversettelse på www.tidsskriftet.no

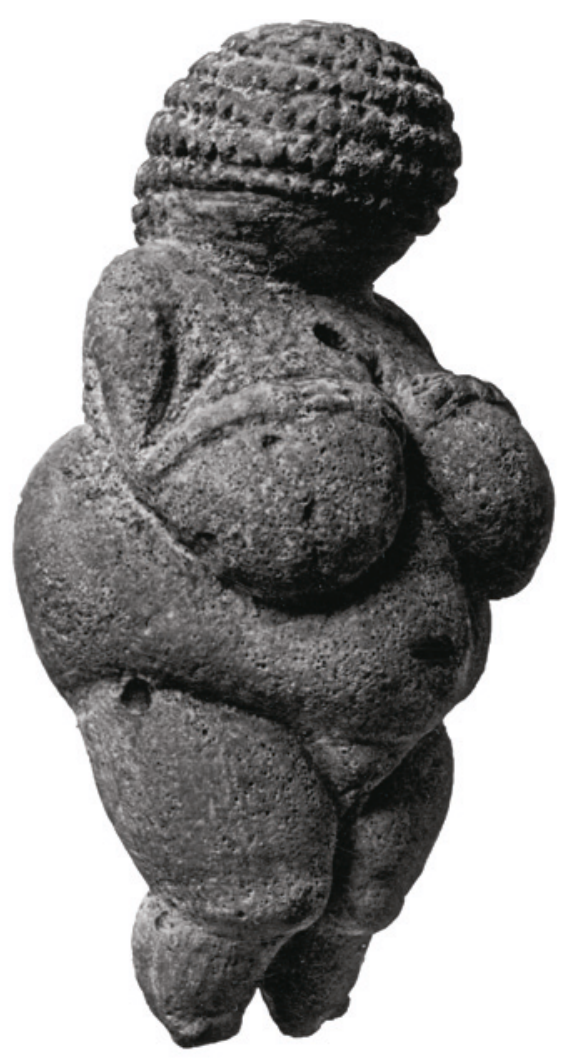


Vi er kjent med at noen mener det er en avgjørende forskjell på å bruke «sykelig overvektige personer» og å bruke «personer med sykelig overvekt». Ifølge dem skulle en adjektivisk uttrykksmåte («sykelig overvektig») stemple et menneske som bare sykelig overvektig («hele sannheten»), mens et preposisjonsuttrykk («med sykelig overvekt») ikke gjør det samme. En slik hypotese har dårlig grunnlag i generell syntaks og semantikk. Valget mellom adjektiv og preposisjonsuttrykk dreier seg først og fremst om muligheten for å variere ordlegging og setningsbygning når en skriver eller snakker.

Ord er ikke bare bærere av betydning i snever forstand («denotasjon»), men også av valører («konnotasjoner»), slik det er pekt på i Sensitive ord (1). Visse betegnelser er klart nedsettende, kanskje fordi de er ment slik, som «drukkenbolt»og «fleskeberg», mens det vil være delte meninger om mange andre, for eksempel «alkoholiker»og «fet». En bør ikke dra dette for langt. At et ord som «funksjonshemmet» skulle virke diskriminerende, stigmatiserende eller støtende, tror vi ligger fjernt fra alminnelig språkfølelse, og vi tillater oss også å tvile på at funksjonshemmede flest oppfatter det slik.

Det er også vanskelig å se at «sykelig overvektig» og «med sykelig overvekt» eller «fet» og «med fedme» i lengden skulle kunne beholde markant ulike konnotasjoner i alminnelig språkbruk. Og forresten vil det være mulig å uttrykke seg både nøytralt, positivt-støttende og negativt-stigmatiserende enten en bruker adjektiver eller preposisjonsuttrykk om en først ønsker å oppnå det ene eller andre.

Disse eksemplene illustrerer etter vårt syn godt hvorfor det er svært vanskelig å formulere prinsipper for ikke-stigmatiserende språkbruk ved hjelp av generelle grammatiske kategorier og prinsipper.

\section{Konklusjon}

Vi er innstilt på å følge Språkrådets råd, men vi vil gjerne høre lesernes mening.

Erlend Hem

erlend.hem@medisin.uio.no

Erlend Hem (f. 1970) er dr.med. og redaktør for Tidsskriftets språkspalte.

\footnotetext{
Litteratur

1. Språkrådet. Sensitive ord. www.sprakradet.no/ sprakhjelp/Skriverad/Sensitive_ord (11.6.2015).
}

Publisert først på nett. 